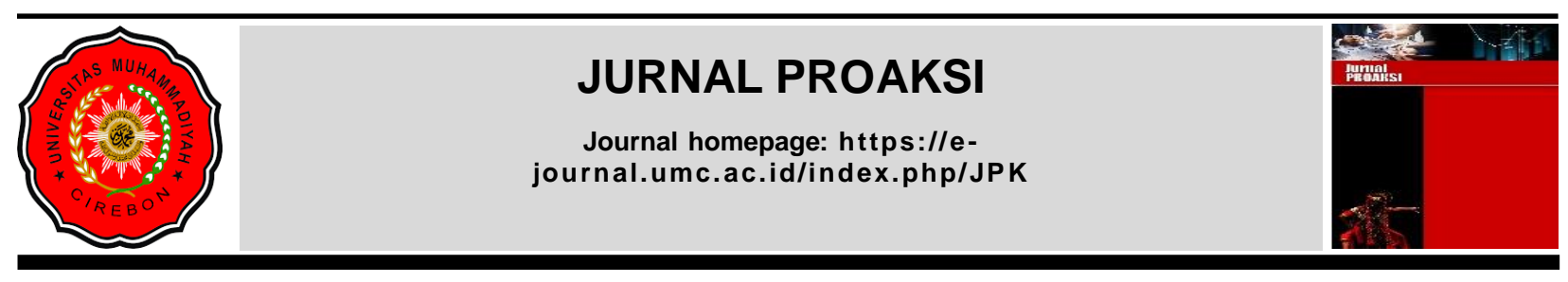

\title{
PENGARUH KEPEMILIKAN MANAJERIAL TERHADAP AGRESIVITAS PAJAK: CORPORATE GOVERNANCE SEBAGAI VARIABEL MODERASI
}

\author{
Ichbal Rachmat Hidayat Ari $\mathbf{S}^{\mathbf{1}}$, \\ Theresia Woro Damayanti ${ }^{2 *}$ \\ ${ }^{1}$ Fakultas Ekonomika dan Bisnis, Universitas Kristen Satya Wacana \\ Email: 232017110@student.uksw.edu \\ ${ }^{2}$ Fakultas Ekonomika dan Bisnis, Universitas Kristen Satya Wacana \\ *Corresponding Author Email: Theresia.damayanti@uksw.edu
}
Diterima : 25 Mei 2021
Direvisi : 16 Juni 2021
Dipublikasikan : 10 Agustus 2021

\begin{abstract}
Abstrak
Tingkat efektivitas pembayaran pajak di Indonesia saat ini belum maksimal, salah satunya dikarenakan masih terdapatnya agresivitas pajak dalam perusahaan manufaktur. Tingkat agresivitas pajak di beberapa negara dapat ditekan dengan melalui tingkat kepemilikan manajerial pada suatu perusahaan. Penelitian ini bertujuan untuk meneliti terkait pengaruh kepemilikan manajerial perusahaan terhadap agresivitas pajak di Indonesia dengan menambahkan variabel moderasi berupa corporate governance. Pada penelitian ini agresivitas pajak diproksikan dengan effective tax rate (ETR) serta corporate governance diproksikan dengan komisaris independen dan komite audit, sedangkan ukuran perusahaan dan return on asset (ROA) sebagai tingkat profitabilitas perusahaan digunakan sebagai variabel kontrol. Pada penelitian ini menggunakan data sekunder berupa data yang diambil dari laporan keuangan perusahaan manufaktur dengan rentan waktu 2015 sampai dengan 2019 (5 tahun). Populasi penelitian ini merupakan perusahaan manufaktur yang sudah terdaftar dalam bursa efek Indonesia (BEI), berdasarkan hasil purposive sampling terdapat 135 perusahaan yang dipakai sebagai sampel. Pada pengujian hipotesis penelitian ini menggunakan pengujian data outlier, statistik deskriptif, uji stasioneritas, uji regresi data panel, dan uji moderasi (MRA). Hasil penelitian ini menunjukkan kepemilikan manajerial tidak berpengaruh terhadap agresivitas pajak di Indonesia dan corporate governance dapat memoderasi serta memperkuat hubungan antara kepemilikan manajerial terhadap agresivitas pajak di Indonesia.
\end{abstract}

Keywords: Agresivitas Pajak, Corporate Governance, Kepemilikan Manajerial

\section{PENDAHULUAN}

Pajak merupakan salah satu sumber dalam penerimaan negara. Negara saat ini terus berupaya dalam pengoptimalan penerimaan pajak, seperti pembaharuan peraturan pajak yang berlaku. Pada dasarnya, fungsi pajak yang diinginkan negara adalah sebagai pengatur dalam mengatasi kesenjangan sosial antar masyarakat dalam hal kepemilikan harta, meskipun tingkatnya tidak terlalu signifikan (Fahmi, 2019). Tingkat efektivitas pembayaran pajak yang kurang menandakan bahwa kondisi di lapangan masih terdapat beberapa kendala dalam efektifitas pembayaran pajak, salah satunya wajib pajak badan yang melakukan agresivitas pajak (Lopo Martinez \& Ferreira, 2019; Mgammal, 2019). Agresivitas pajak menggunakan celah dari peraturan pajak yang belum tersentuh atas (Ayuntina, 2016; Runtu \& Poputra, 2014)perlakuannya maupun menggunakan perencanaan penghematan pajak yang bersifat ilegal. Agresivitas pajak perusahaan dapat dilakukan dalam berbagai cara misalnya melakukan penundaan dalam pengakuan pendapatan, manajemen laba, dan harga transfer (transfer pricing) (Amidu et al., 2019; Salehi \& Salami, 2020). Salah satu contoh kasus agresivitas pajak adalah kasus penghindaran pajak yang 
dilakukan oleh Google sebesar 327 triliun rupiah dengan menggunakan metode double irish, dutch sandwich. Metode ini dipakai oleh Google untuk memindahkan pendapatan dari luar Amerika ke perusahaan cangkang yang memiliki tingkat pajak rendah, sehingga pajak yang ditanggung oleh perusahaan Google menjadi lebih sedikit (Kutera, 2017; Sebayang, 2019). Dalam hal ini dapat dilihat bahwa pihak manajer terlibat dalam pembuatan keputusan tersebut, di mana Google menetapkan kebijakan dalam hal praktik agresivitas pajak semaksimal mungkin agar bisa mengurangi pembebanan pajak yang diterima. Dalam sebuah perusahaan, terdapat pihak-pihak yang berpengaruh terhadap pembuatan dan pengambilan kebijakan, diantaranya kepemilikan institusional dan kepemilikan manajerial (Faysal et al., 2020).

Kepemilikan manajerial dalam sebuah perusahaan terdiri dari pihak komisaris dan direksi. Kepemilikan manajerial memiliki peran penting dalam membuat sebuah kebijakan perusahaan seperti kebijakan investasi, pembagian dividen, dan kebijakan pajak seperti agresivitas pajak (Feng et al., 2019; Mutmainnah et al., 2019). Semakin besar tingkat kepemilikan manajerial terhadap saham di perusahaan maka kepemilikan manajerial memiliki dua kepentingan, yakni kepentingan pemegang saham beserta kepentingan terhadap menjalankan perusahaan seperti peningkatan aktivitas operasional dan nilai perusahaan (Subekti \& Amin, 2019; Tambalean et al., 2018). Allam (2018) menyatakan perbedaan kepentingan yang dimiliki antara pemegang saham dengan pihak manajemen perusahaan (agency problems) dapat ditekan oleh kepemilikan manajerial. Agar kepemilikan manajerial dapat bekerja dengan baik dibutuhkan juga peran dari tata kelola dalam perusahaan (corporate governance) (Maharani \& Suardana, 2014). Corporate governance merupakan tata kelola dalam sebuah perusahaan agar mampu meningkatkan daya saing dalam perekonomian. Corporate governance bersifat mengatur dan mengawasi perusahaan dalam memenuhi kewajibannya terhadap pemangku kepentingan, seperti transparansi laporan keuangan yang lebih terperinci (Maraya \& Yendrawati, 2016). Selain itu, semakin tinggi kualitas corporate governance dalam perusahaan akan berpengaruh dengan tingkat tarif efektivitas pajak (Kiesewetter \& Manthey, 2017). Kovermann \& Velte (2019) menyebutkan faktor corporate governance yang mempengaruhi agresivitas pajak diantaranya kualitas audit, institusi pemerintahan, struktur kepemilikan perusahaan, struktur komisaris, dan lainnya.

Penelitian tentang kepemilikan manajerial mengenai agresivitas pajak telah dilakukan di berbagai negara. Cabello et al. (2019) menjelaskan kepemilikan manajerial dengan tingkat 40\% sampai 50\% dalam sebuah perusahaan dapat mempengaruhi penekanan agresivitas pajak di Brazil. Abdelfattah \& Aboud (2020) menjelaskan corporate governance juga berpengaruh terhadap agresivitas pajak di Mesir. Hal tersebut disebabkan karena, corporate governance pengaruh terhadap pemberitaan corporate social responsibility (CSR) kepada pihak luar dan agresivitas pajak perusahaan di Mesir menjadi turun.

Berdasarkan hasil penelitian yang telah dilakukan sebelum-sebelumnya, penelitian ini bertujuan untuk meneliti pengaruh kepemilikan manajerial perusahaan terhadap agresivitas pajak di Indonesia dengan menambahkan variabel moderasi berupa corporate governance. Variabel corporate governance dinilai mampu menekan agresivitas pajak dari segi pelaporan kepada pihak eksternal melalui pelaporan CSR dengan tingkat transparansi yang lebih tinggi. Agresivitas pajak pada perusahaan dapat menjadi agresif diakibatkan dari kebijakan penghematan pajak yang terlalu intens dan telah diputuskan sebelumnya oleh pemilik perusahaan. Hal tersebut dapat memungkinkan bahwa perusahaan bisa saja melakukan agresivitas pajak dengan bebas, karena di dalam perusahaan tersebut bisa saja belum memiliki corporate governance.

Berdasarkan latar belakang yang sudah dijabarkan, rumusan masalah pada penelitian ini yaitu apakah kepemilikan manajerial mempengaruhi agresivitas pajak di Indonesia? Apakah corporate governance dapat memoderasi hubungan kepemilikan manajerial terhadap agresivitas pajak di Indonesia? Adapun manfaat pada penelitian ini akan menjadi tambahan literatur terhadap faktor-faktor yang mempengaruhi agresivitas pajak di Indonesia dan menjadi tambahan informasi bagi pemerintah bahwa kepemilikan manajerial mampu menekan agresivitas pajak. Hal ini disebabkan, tingkat kepemilikan manajerial yang tinggi dinilai mampu menekan agresivitas pajak dengan cara membantu pihak manajer dalam menentukan keputusan untuk tidak melakukan agresivitas pajak. 


\section{KAJIAN PUSTAKA DAN PEGEMBANGAN HIPOTESIS Teori Agensi (Agency Theory)}

Teori agensi merupakan teori yang menjabarkan hubungan principal dengan agent pada perusahaan (Tambalean et al., 2018). Pada teori ini pemegang saham (principal) dan manajer perusahaan (agent) memiliki hubungan, dalam hal menyejahterakan para pemegang saham dan memutuskan kebijakan yang terbaik bagi para pemegang saham dengan cara pembagian dividen atas penanaman investasi dalam perusahaan (Jensen \& Meckling, 1976). Pembagian dividen merupakan bentuk feedback dari manajer perusahaan terhadap pemegang saham dalam memberi rasa kepercayaan dalam membeli saham yang telah dikeluarkan oleh perusahaan (Bailey, 1989). Pada teori ini juga membahas tentang pemisahan kepentingan antara pemegang saham beserta manajer perusahaan (Mulyani et al., 2018). Pada teori ini, manajer perusahaan memiliki kekuasaan dalam pengambilan keputusan secara sepihak (Eisenhardt, 1989; Liviani et al., 2016). Jika, manajer perusahaan melakukan pengambilan keputusan sepihak dapat menimbulkan adanya agency problems dengan pemegang saham (Sintyawati \& Dewi, 2018). Agency problems merupakan permasalahan yang disebabkan perbedaan kepentingan dan berpengaruh terhadap penurunan kinerja serta nilai perusahaan (Mutmainnah et al., 2019; Yee et al., 2018).

\section{Kepemilikan Manajerial (Managerial Ownership)}

Kepemilikan manajerial merupakan saham yang dimiliki oleh pihak direksi dan komisaris perusahaan. Semakin tinggi tingkat saham yang dimiliki manajerial dalam perusahaan, membuat kepemilikan manajerial lebih berhati-hati dalam membuat kebijakan yang lebih matang (Fadhila et al., 2017; Munisi et al., 2014). Sunarsih \& Handayani (2018) menjelaskan kepemilikan manajerial digunakan sebagai penekan terhadap terjadinya agency problems pada perusahaan. Oleh karena itu, kepemilikan manajerial dinilai berhasil dalam menyeimbangkan kebijakan yang dilakukan perusahaan dengan kesejahteraan para pemegang saham (Sintyawati \& Dewi, 2018).

\section{Agresivitas Pajak (Tax Aggressiveness)}

Agresivitas pajak merupakan praktik penghematan yang dipakai wajib pajak badan dalam pembayaran kewajiban pajak kepada negara (Cuesta-González \& Pardo, 2019; Maraya \& Yendrawati, 2016). Agresivitas pajak merupakan perencanaan penghematan pajak baik secara ilegal maupun legal. Salah satu contoh agresivitas pajak secara legal adalah pemanfaatan peraturan pajak yang belum jelas secara pastinya terkait perlakuan maupun tarif yang digunakan (Hidayat, 2018; Utama et al., 2019). Perusahaan akan bersifat agresif dalam mengurangi beban pajak yang ditanggung apabila pemanfaatan celah ilegal dan legal secara besar dan hal tersebut cukup berpotensi merugikan negara serta ada kemungkinan terkena sanksi ataupun denda (Tiaras \& Wijaya, 2015). Alasan wajib pajak badan melakukan agresivitas pajak, karena tarif yang dibebankan kepada wajib pajak jika diakumulasikan dengan pajak yang lain cukup memberatkan (Cabello et al., 2019). Oleh karena itu, wajib pajak melakukan agresivitas pajak dengan tujuan agar dapat menghemat pembayaran pajak terhadap negara (Dyreng et al., 2010).

\section{Corporate Governance}

Maraya \& Yendrawati (2016) menjelaskan corporate governance merupakan metode yang dipakai pada sebuah perusahaan dalam mengawasi dan mengatur manajer perusahaan agar menjalankan tugasnya dengan baik, sehingga kualitas perusahaan semakin tinggi yang ditandai dengan meningkatnya kondisi keuangan perusahaan. Kondisi keuangan perusahaan yang semakin meningkat menandakan bahwa corporate governance berhasil mengontrol manajer agar menjalankan visi misi perusahaan dan mewujudkan kepetingan para pemegang saham baik dari pihak eksternal maupun internal. Komite Nasional Kebijakan Corporate Governance (2008) menjelaskan terdapat 5 asas-asas di dalam Corporate governance yakni: Penyediaan informasi yang ada haruslah memadai dan transparan (Transparency); Pertanggungjawaban atas kejelasan kinerja perusahaan (accountability); Memperlakukan asas kewajaran

dan kesetaraan kepada para pemangku kebijakan (fairness); Perusahaan mengakui adanya perbedaan opini terhadap sebuah kepentingan (democracy); Menjunjung tinggi penegakan hukum yang ada dalam sebuah perusahaan (legal culture). 


\section{Pengaruh kepemilikan manajerial terhadap agresivitas pajak}

Berdasarkan agency theory, agresivitas pajak kemungkinan keputusan yang ditetapkan secara pribadi yang dilakukan oleh pihak manajer agar dapat menurunkan kewajiban pajak sekecil mungkin, dengan cara penurunan laba operasional perusahaan (Amidu et al., 2019; Ortas \& Gallego-Álvarez, 2020). Pengambilan keputusan secara pribadi yang dilakukan oleh pihak manajer terkait penghematan pembayaran pajak ada kemungkinan pihak manajer akan mengesampingkan kepentingan dalam menyejahterakan para pemegang saham, sehingga agency problems antara pemegang saham beserta manajer perusahaan tidak bisa dihindari (Salehi et al., 2019). Oleh karena itu, kepemilikan manajerial diperlukan dalam sebuah perusahaan untuk mengatasi timbulnya agency problems (Jensen \& Meckling, 1976; Liviani et al., 2016). Allam (2018) menjelaskan kepemilikan manajerial dinilai mampu membuat keputusan lebih matang tanpa mengesampingkan kepentingan dari pemegang saham, termasuk dalam kebijakan agresivitas pajak. Sunarsih \& Handayani (2018) menjelaskan kepemilikan manajerial mampu mempengaruhi agresivitas pajak, karena kepemilikan manajerial akan berhati-hati dalam membuat keputusan. Dalam hal ini, pengalaman yang dimiliki oleh kepemilikan manajerial berperan penting dalam memberikan kebijakan yang lebih efektif dan efisien dengan tingkat risiko yang akan timbul cukup rendah serta memiliki langkah dalam penanggulangan atas risiko tersebut (Subekti \& Amin, 2019). Oleh karena itu, hipotesis dalam penelitian ini dijabarkan sebagai berikut:

H1: Kepemilikan manajerial berpengaruh negatif terhadap agresivitas pajak.

\section{Pengaruh corporate governance dalam hubungan kepemilikan manajerial terhadap agresivitas pajak}

Komite Nasional Kebijakan Corporate Governance (2008) menjelaskan corporate governance diperlukan oleh negara karena dianggap sebagai salah satu faktor dalam memajukan perusahaan. Corporate governance digunakan agar dapat membantu perusahaan dalam meningkatkan kualitasnya melalui tingkat transparansi atas kinerja keuangan perusahaan kepada publik sebagai bentuk pertanggungjawabannya terhadap pihak eksternal (La Rosa et al., 2020). Corporate governance dinilai dapat membantu kepemilikan manajerial dalam mencegah perusahaan melakukan pengambilan keputusan sepihak (Mutmainnah et al., 2019). Meskipun kepemilikan manajerial dinilai dapat menekan agency problems, akan tetapi manajer yang selaku pemimpin perusahaan bisa saja melakukan pengambilan keputusan secara sepihak tetapi tidak terdeteksi oleh pihak eksternal dan bisa saja tingkat transparansi kepada pihak pemegang saham belum maksimal (Neifar \& Utz, 2019; L. Wang, 2015). Tingkat transparansi yang belum maksimal menandakan bahwa corporate governance sangat diperlukan dalam pengawasan kepemilikan manajerial terutama dalam penurunan agresivitas pajak perusahaan (Ortas \& Gallego-Álvarez, 2020; Sunarsih \& Handayani, 2018). Abdelfattah dan Aboud (2020); Salhi et al. (2019) menyatakan penerapan corporate governance dalam sebuah perusahaan mampu berpengaruh terhadap pengungkapan CSR yang sebagai salah satu faktor dalam menurukan agresivitas pajak. Hal tersebut disebabkan karena, corporate governance membantu para pihak eksternal dalam melihat pertanggungjawaban perusahaan atas kinerja yang dilakukan. Dengan adanya corporate governance dapat membantu pihak eksternal mengetahui apakah perusahaan melakukan agresivitas pajak atau tidak, dengan cara melihat pelaporan CSR dengan tingkat transparansi lebih baik. Hipotesis kedua dalam penelitian ini dijabarkan sebagai berikut:

$\mathrm{H} 2$ : Corporate governance memperkuat hubungan kepemilikan manajerial terhadap agresivitas pajak.

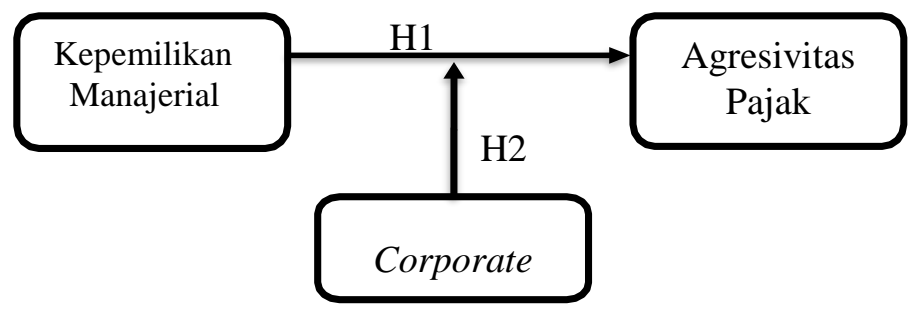

Gambar 1 Model Penelitian 


\section{METODE PENELITIAN}

Penelitian ini menggunakan perusahaan manufaktur yang tercantum dalam Bursa Efek Indonesia (BEI) sebagai objek penelitiannya. Perusahaan manufaktur digunakan sebagai objek penelitian karena memiliki potensi lebih untuk mengurangi kewajiban pembayaran pajak yang ditanggung. Pajak yang ditanggung dan harus dibayarkan oleh perusahaan manufaktur cukup beragam, yakni PPN, PPH 21, PPH 22, PPH 23, dan lain sebagainya. Penelitian ini menggunakan data sekunder yang didapat dari website Bursa Efek Indonesia/ IDX.co.id dan website perusahaan yang terkait. Pengumpulan data pada penelitian ini memakai metode purposive sampling, oleh karena itu kriterianya berisi:

1. Perusahaan yang sudah terdaftar dalam BEI minimal 3 tahun.

2. Perusahaan yang memublikasikan laporan tahunan dengan rentan tahun 20152019.

3. Perusahaan yang tidak mengalami kerugian selama tahun pengamatan.

4. Data yang ada di perusahaan tersedia secara lengkap terhadap variabel yang akan diteliti.

\section{Variabel Dependen}

Agresivitas pajak merupakan sebuah skema yang dipakai wajib pajak dalam mengurangi beban pajak yang ditanggung. Praktik agresivitas pajak dilakukan melalui pemangkasan laba perusahaan sehingga pendapatan setelah pajak menjadi kecil (Feng et al., 2019). Pengukuran dalam agresivitas pajak pada peneitian ini menggunakan proksi Effective Tax Rate (ETR). ETR dihitung dari hasil perbandingan antara beban pajak yang ditanggung perusahaan dengan pendapatan sebelum pajak. Semakin besar nilai ETR maka tingkat agresivitas pajak semakin turun, sehingga menandakan bahwa beban pajak yang ditanggung oleh perusahaan semakin besar (A. Saputra, 2020). Beban pajak yang ditanggung perusahan merupakan cerminan dari tingkat agresivitas pajak yang terjadi dalam sebuah perusahaan (Jayanto Purba \& Kuncahyo, 2020).

$$
\mathrm{ETR}=\frac{\text { Beban Pajak }}{\text { Laba Sebelum Pajak }} \times 100 \%
$$

\section{Variabel Independen}

Kepemilikan manajerial merupakan kepemilikan saham yang dipegang pihak direksi dan komisaris (Fadhila et al., 2017). Kepemilikan manajerial digunakan sebagai langkah tepat dalam menekan agency problems yang disebabkan adanya perbedaan kepentingan antara pihak agent dengan principal. Pengukuran tingkat kepemilikan manajerial perusahaan dilihat dari total saham beredar yang dipegang pihak komisaris dan direksi (Sunarsih \& Handayani, 2018). Rasio yang digunakan untuk menghitung kepemilikan manajerial sebagai berikut:

$$
K P M J=\frac{\text { Total Saham yang dimiliki oleh Manajerial }}{\text { Total Saham Beredar }} \times 100 \%
$$

\section{Variabel Moderasi}

Corporate Governance merupakan pengawasan yang digunakan kepada perusahaan dalam menjalankan kewajibannya. Komite Nasional Kebijakan Corporate Governance (2008) menjelaskan Corporate Governance mampu mempengaruhi agresivitas pajak perusahaan. Karena pemilik perusahaan diharuskan mengungkapkan kinerja yang ada di perusahaan setransparansi mungkin. Perhitungan corporate governance dalam penelitian ini diproksikan dengan dua perhitungan yakni komisaris independen dan komite audit (M. D. R. Saputra \& Asyik, 2017).

$$
\text { Komisaris Independen }=\frac{\text { Total } \text { Komisaris Independen }}{\text { Total } \text { Komisaris }}
$$

\section{Komite Audit = Total Komite Audit dalam Sebuah Perusahaan}

\section{Variabel Kontrol}

Pada penelitian ini ukuran perusahaan dan tingkat profitabilitas perusahaan digunakan sebagai variabel kontrol (Bimo et al., 2019; Yee et al., 2018). Ukuran perusahaan yang besar membuat perhatian 
pihak eksternal pada perusahaan akan semakin tinggi. Hal ini dikarenakan, ukuran perusahaan yang besar menandakan kepemilikan atas asset juga semakin besar dan laporan keuangannya lebih stabil daripada perusahaan dengan ukuran yang lebih kecil, sehingga pihak eksternal lebih memilih perusahaan besar untuk dibeli sahamnya (Prena et al., 2018). Perusahaan yang semakin besar ukuran atau asset yang dimiliki, maka ada kemungkinan perusahaan tersebut melakukan agresivitas pajak (Lopo Martinez \& Ferreira, 2019; Wahyuni et al., 2019). Dengan demikian, ukuran perusahaan mempengaruhi terhadap agresivitas pajak (Suryandani, 2018).

\section{$\mathrm{S} I Z E=$ Total aset yang dimiliki}

Tingkat profitabilitas menampilkan kemampuan perusahaan dalam mengelola aset. Semakin efektif perusahaan dalam mengelola asetnya, maka tingkat profitabilitas semakin tinggi. Tingkat profitabilitas perusahaan yang tinggi menandakan kewajiban pajak yang dibayarkan semakin tinggi (Su et al., 2019). Langkah yang dilakukan perusahaan untuk tetap mendapatkan profitabilitas adalah dengan melakukan tax planning seefektif mungkin yaitu melakukan penekanan biaya, karena dengan penekanan biaya maka kewajiban pajak yang dibebankan semakin turun (T. Wang, 2019). Dengan demikian, perusahaan dengan tingkat profitabilitas tinggi akan menjalankan agresivitas pajak (Salehi \& Salami, 2020; Zhang et al., 2016). Tingkat profitabilitas perusahaan dalam penelitian ini dapat diukur dengan Return on Asset (ROA) (Higgins et al., 2015).

$$
R O A=\frac{\text { Pendapatan Sebelum Pajak }}{\text { Total Aset }} \times 100 \%
$$

\section{Metode Analisis Data}

Pengujian pada penelitian ini menggunakan uji regresi data panel dengan menggunakan pengolahan Eviews, karena data yang digunakan data cross sectional beserta time series. Data cross sectional beserta time series digunakan karena data yang akan diteliti berasal dari berbagai laporan perusahaan dalam sektor manufaktur dengan waktu yang yang sudah ditentukan.

1. Statistik Deskriptif

Dalam pengujian ini, statistik deskriptif dipakai untuk memunculkan informasi-informasi dari data yang tersedia dengan digambarkan dalam bentuk nilai/ angka pada sebuah tabel. Data yang kemungkinan ada dalam statistik deskriptif seperti standar deviasi, nilai minimum, nilai maksimum, median, dan rata-rata.

2. Uji stasioneritas

Pengujian ini digunakan untuk menguji data yang dipakai tidak mengalami perubahan dari waktu ke waktu atau bersifat konstan. Pengujian ini menggunakan uji individual root-fisher- $A D F$ dan mengecek setiap data variabel apakah mengalami stasioneritas ataukah tidak. Data akan bersifat stasioner jika nilai probabilitas fisher-ADF chi-square kecil dari 0,05. Data akan bersifat tidak stasioner jika nilai probabilitas fisher-ADF chi-square besar dari 0,05 dan perlu melakukan pengujian lagi pada tingkat uji root selanjutnya.

3. Metode Regresi Data Panel

Pengujian yang dipakai dalam metode regresi data panel menggunakan pengujian sebagai berikut:

a. Uji Chow

Pengujian ini dipakai dalam memastikan model yang akan digunakan antara model fixed effect ataukah model common effect. Untuk menentukan model fixed effect maupun model common effect, bisa diamati dari nilai probabilitas cross-section chi-square terhadap 0,05. Jika nilai probabilitas cross-section chi-square lebih besar dari 0,05 maka model yang dipakai adalah model common effect. Jika nilai probabilitas cross-section chi-square lebih kecil dari 0,05 maka model yang dipakai adalah model fixed effect.

b. Uji Hausman

Pengujian ini dipakai dalam memastikan model yang lebih unggul antara model random effect ataukah model fixed effect. Untuk menentukan model random effect maupun model fixed effect, bisa diamati dari nilai probabilitas cross-section random terhadap nilai 0,05 . Jika 
nilai probabilitas cross-section random lebih besar dari 0,05 , maka model random effect yang dipilih. Jika nilai probabilitas cross-section random lebih kecil dari 0,05 , maka model fixed effect yang dipilih.

c. Uji Lagrange Multiplier (LM)

Pengujian ini dipakai untuk memastikan model yang akan dipakai antara model common effect ataukah model random effect. Untuk menentukan model common effect maupun model random effect, bisa diamati dari nilai both breusch-pagan terhadap 0,05. Jika nilai both breusch-pagan lebih besar dari 0,05 maka model yang dipakai adalah model common effect. Jika nilai nilai both breusch-pagan lebih kecil dari 0,05 maka model yang dipakai adalah model random effect.

4. Uji Hipotesis

Dalam penelitian ini terdapat dua model pengujian untuk menguji hipotesis. Pengujian hipotesis pertama mengenai kepemilikan manajerial berpengaruh negatif terhadap agresivitas pajak. Pengujian hipotesis kedua mengenai corporate governance memperkuat hubungan kepemilikan manajerial terhadap agresivitas pajak di Indonesia. Sehingga persamaan matematis dalam pengujian ini dapat dirumuskan sebagai berikut:

$$
\begin{aligned}
& \text { 1. } \mathrm{ETR} 1=\alpha \text { it }-\beta 1 \mathrm{KPMJit}+\beta 2 \text { SIZEit }+\beta 3 \text { ROAit }+\varepsilon \text { it } \\
& \text { 2. } \mathrm{ETR} 2=\alpha \text { it }-\beta 1 \mathrm{KPMJit}+\beta 2 \text { SIZEit }+\beta 3 \text { ROAit } * \text { CGit }+\varepsilon \text { it }
\end{aligned}
$$

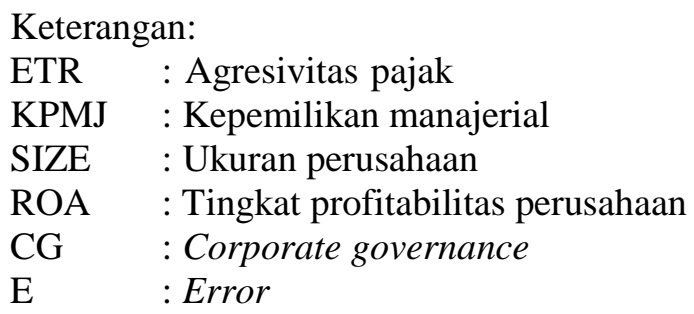

Berdasarkan hasil pengujian diatas, hipotesis akan diterima atau tidak dilihat dari nilai probabilitas terhadap tingkat signifikansi 0,05 . Pada hipotesis pertama dapat dinyatakan diterima jika nilai probabilitas pada variabel independen pada model terbaik lebih kecil dari 0,05. Hipotesis kedua dapat dinyatakan memoderasi jika nilai probabilitas dari $\mathrm{M}$ lebih kecil dari 0,05, sedangkan untuk melihat memperkuat atau memperlemah dilihat dari adjusted r-squared dalam determinan terhadap nilai adjusted $r$-squared dalam perhitungan moderasi. Variabel moderasi dikatakan memperkuat hubungan variabel independen terhadap variabel dependen jika adjusted r-squared dalam determinasi awal lebih kecil dari nilai adjusted $r$ squared setelah melakukan moderasi. Variabel moderasi dikatakan memperlemah hubungan variabel independen terhadap variabel dependen jika adjusted $r$-squared dalam determinasi awal lebih besar dari nilai adjusted $r$-squared setelah melakukan moderasi.

\section{HASIL DAN PEMBAHASAN}

Penelitian ini menggunakan populasi perusahaan manufaktur yang terdaftar dalam BEI minimal 3 tahun sebanyak 555 perusahaan. Berdasarkan teknik purposive sampling, pada penelitian ini memiliki sampel akhir sebanyak 135 perusahaan manufaktur dengan kriteria sampel sebagai berikut:

Tabel 1

Purposive Sampling

\begin{tabular}{lc}
\hline \multicolumn{1}{c}{ Kriteria Sampel } & Jumlah Sampel \\
\hline $\begin{array}{l}\text { Laporan keuangan perusahaan manufaktur yang terdaftar dalam Bursa Efek Indonesia } \\
\text { (BEI) pada periode tahun 2015-2019 dan sudah terdaftar di dalam BEI minimal 3 } \\
\text { tahun }\end{array}$ & $\mathbf{5 5 5}$ \\
\hline Laporan keuangan perusahaan manufaktur yang mengalami kerugian & $\mathbf{( 9 6 )}$ \\
\hline $\begin{array}{l}\text { Laporan keuangan yang tidak diterbitkan oleh perusahaan manufaktur selama periode } \\
\text { 2015-2019 }\end{array}$ & $\mathbf{( 8 2 )}$ \\
\hline
\end{tabular}

Fakultas Ekonomi, Universitas Muhammadiyah Cirebon 


\begin{tabular}{ll}
\hline $\begin{array}{l}\text { Data laporan keuangan yang disajikan tidak lengkap terhadap variabel yang } \\
\text { diperlukan }\end{array}$ & $\mathbf{( 1 8 9 )}$ \\
\hline Laporan keuangan yang termasuk dalam data outlier & $\mathbf{( 5 3 )}$ \\
\hline Jumlah sampel akhir yang digunakan & $\mathbf{1 3 5}$ \\
\hline
\end{tabular}

\section{Statistik Deskriptif}

Hasil statistik deskriptif pada penelitian ini setelah diolah menggunakan aplikasi eviews sebagai berikut:

Tabel 2

Hasil Statistik Deskriptif

\begin{tabular}{cccccc}
\hline & Rata-rata & Median & Maksimum & Minimum & St. Deviasi \\
\hline ETR & 0,437151 & 0,252900 & 1,017140 & 0,016500 & 1,086861 \\
\hline KPMJ & 0,161183 & 0,059400 & 1,000000 & 0,000100 & 0,225145 \\
\hline SIZE & 1,361060 & 2,295735 & 2,434618 & 20498,00 & 3,152849 \\
\hline ROA & 0,084592 & 0,072700 & 0,321800 & 0,001100 & 0,067478 \\
\hline CG & 1,736889 & 1,670000 & 2,800000 & 1,590000 & 0,192944 \\
\hline
\end{tabular}

Sumber: Data sekunder yang sudah diolah

Dari hasil tabel diatas jumlah sampel yang digunakan untuk pengujian sebesar 135 sampel perusahaan manufaktur yang terdaftar dalam Bursa Efek Indonesia. Variabel agresivitas pajak yang diproksikan dengan ETR memiliki nilai rata-rata sebesar 0,437151 dan nilai median sebesar 0,252900 sehingga tingkat agresivitas pajak dalam perusahaan manufaktur dapat dikatakan tinggi. Pada variabel ETR dapat dilihat bahwa tingkat agresivitas pajak pada perusahaan manufaktur sebesar $43 \%$, tingkat agresivitas tertinggi berada dalam perusahaan LION dan agresivitas pajak terendah berada dalam perusahaan ESTI. Nilai rata-rata kepemilikan manajerial dalam perusahaan manufaktur sebesar 0,161183 dan nilai median sebesar 0,252900 sehingga tingkat kepemilikan manajerial dalam perusahaan manufaktur dapat dikatakan tinggi. Pada variabel tingkat kepemilikan manajerial dapat dilihat tingkat maksimumnya pada perusahaan DMND dan tingkat terendah pada perusahaan NIKL.

Nilai rata-rata ukuran perusahaan dalam perusahaan manufaktur yang merupakan proksi dari variabel kontrol sebesar 1.361.060.202.939 dan nilai median sebesar 2.305.734.967, sehingga tingkat kepemilikan manajerial dalam perusahaan manufaktur dapat dikatakan masih rendah. Pada variabel tingkat ukuran perusahaan dapat dilihat tingkat maksimumnya pada perusahaan INDS dan tingkat terendah pada perusahaan ASII. Nilai rata-rata ROA dalam perusahaan manufaktur yang merupakan proksi dari variabel kontrol sebesar 0,084592 dan nilai median sebesar 0,072700 sehingga tingkat ROA dalam perusahaan manufaktur dapat dikatakan sudah optimal/ tinggi. Pada variabel ROA dapat dilihat tingkat maksimumnya pada perusahaan BRAM dan tingkat terendah pada perusahaan LION. Nilai ratarata corporate governance dalam perusahaan manufaktur sebesar 1,736889 dan nilai median sebesar 1,670000 sehingga tingkat corporate governance dalam perusahaan manufaktur dapat dikatakan sudah optimal/ tinggi. Pada variabel corporate governance dapat dilihat tingkat maksimumnya pada perusahaan LION dan tingkat terendah pada perusahaan AGII.

\section{Uji Stasioneritas}

Hasil uji stasioneritas pada penelitian ini untuk mengetahui data yang digunakan bersifat konstan sebagai berikut:

Tabel 3

Hasil Uji Stasioneritas

\begin{tabular}{ccc}
\hline Variabel & $\begin{array}{c}\text { Nilai Probabilitas Fisher- } \\
\text { ADF Chi-square }\end{array}$ & $\begin{array}{c}\text { Keterang } \\
\text { an }\end{array}$ \\
\hline ETR & 0,0000 & Stasioner \\
\hline
\end{tabular}


Jurnal Proaksi, Vol. 8 (2), Hal. 329 - 343

\begin{tabular}{lll}
\hline KPMJ & 0,0000 & Stasioner \\
\hline SIZE & 0,0000 & Stasioner \\
\hline ROA & 0,0000 & Stasioner \\
\hline CG & 0,0000 & Stasioner \\
\hline
\end{tabular}

Sumber: Data sekunder yang sudah diolah

Dari hasil data tabel diatas menjelaskan bahwa ETR yang merupakan variabel dependen bersifat stasioner dan dapat dilihat dari nilai probabilitas Augmented ADF test statistic lebih kecil dari 0,05 yakni, 0,0000. KPMJ sebagai variabel independen bersifat stasioner dan dapat dilihat dari nilai probabilitas Augmented ADF test statistic lebih kecil dari 0,05 yakni, 0,0000. SIZE dan ROA sebagai variabel kontrol bersifat stasioner dan dapat dilihat dari nilai probabilitas Augmented ADF test statistic lebih kecil dari 0,05 yakni, 0,0000. CG sebagai variabel moderasi bersifat stasioner dan dapat dilihat dari nilai probabilitas Augmented ADF test statistic lebih kecil dari 0,05 yakni, 0,0000.

\section{Regresi Data Panel}

Hasil uji regresi data panel untuk mengetahui model terbaik dari persamaan matematis 1 dan 2 pada penelitian ini sebagai berikut:

Tabel 4

Hasil Uji Regresi Data Panel

\begin{tabular}{cccc}
\hline Uji & Model & Hasil & Model Terbaik \\
\hline Uji Chow & 1 & Prob. 0,6815>0,05 & Common Effect Model \\
\hline & 2 & Prob. 0,6898>0,05 & Common Effect Model \\
\hline Uji Hausman & 1 & Prob. 0,8783>0,05 & Random Effect Model \\
\hline $\begin{array}{c}\text { Uji Lagrange } \\
\text { Multiplier }\end{array}$ & 2 & Prob. 0,6894>0,05 & Random Effect Model \\
\hline & 2 & Both. 0,1421>0,05 & Common Effect Model \\
\hline
\end{tabular}

Sumber: Data sekunder yang sudah diolah

Hasil dari uji chow pada model 1 dan 2 dapat diputuskan menggunakan common effect model, karena nilai probabilitas cross-section chi-square dari masing-masing model 1 dan 2 lebih besar dari 0,05 yakni 0,6815 dan 0,6898. Hasil dari uji hausman pada model 1 dan 2 dapat diputuskan menggunakan random effect model, karena nilai probabilitas cross-section random dari masing-masing model 1 dan 2 lebih besar dari 0,05 yakni 0,8783 dan 0,6894. Hasil dari uji lagrange multiplier pada model 1 dapat diputuskan menggunakan common effect model, karena nilai both breusch-pagan dari model 1 lebih besar dari 0,05 yakni 0,1421. Hasil uji lagrange multiplier pada model 2 dapat diputuskan menggunakan random effect model, karena nilai both breusch-pagan lebih kecil dari 0,05 yakni 0,0171.

\section{Pengujian Hipotesis}

Berdasarkan hasil dari uji metode regresi data panel melalui eviews diantaranya uji chow, uji hausman, uji lagrange multiplier (LM). Dari hasil uji Lagrange Multiplier (LM) menghasilkan model terbaik dalam pengujian hipotesis pertama yakni common effect model.

Tabel 5

Penggunaan Model Terbaik

\begin{tabular}{ccc}
\hline \multicolumn{3}{c}{ Common Effect Model } \\
\hline Variabel & Koefisien & Probabilitas \\
\hline C & 0,779168 & 0,0000 \\
\hline KPMJ & $-0,270292$ & 3,568056 \\
\hline SIZE & $-1,799305$ & 3,767361 \\
\hline
\end{tabular}




\begin{tabular}{ccc}
\hline ROA & $-3,238.616$ & 0,140278 \\
\hline Sumber: Data sekunder yang sudah diolah
\end{tabular}

Berdasarkan dari hasil tabel diatas dapat dinyatakan bahwa nilai probabilitas dari variabel kepemilikan manajerial 3,5680 >0,05 sehingga kepemilikan manajerial tidak berpengaruh terhadap agresivitas pajak dan hipotesis 1 dinyatakan tidak dapat diterima atau ditolak.

Tabel 6

Hasil Uji Moderasi Corporate Governance

\begin{tabular}{lll}
\hline & \multicolumn{1}{c}{ Moderasi Corporate Governance } \\
\hline Variabel & Koefisien & Probabilitas \\
\hline C & $-3,884548$ & 0,0001 \\
\hline KPMJ & 7,301283 & 0,07222 \\
\hline SIZE & $-9,144550$ & 5,21042 \\
\hline ROA & $-3,010121$ & 0,19444 \\
\hline CG & $1,498,202$ & 0,0000 \\
\hline M1 & $-2,424927$ & 0,0079 \\
\hline
\end{tabular}

Sumber: Data sekunder yang sudah diolah

Tabel 7

Perbandingan Hasil Adjusted R-Squared

\begin{tabular}{ccc}
\hline \multicolumn{3}{c}{ Adjusted $R$-Squared } \\
\hline Sebelum uji moderasi & 0,026438 & Keterangan \\
\hline Setelah uji Moderasi & 0,180450 & $\begin{array}{c}\text { Lebih besar dari } \text { adjusted } r \text { - } \\
\text { Squared sebelumnya }\end{array}$ \\
\hline \multicolumn{2}{c}{ Kesimpulan } & Memperkuat Moderasi \\
\hline
\end{tabular}

Sumber: Data sekunder yang sudah diolah

Berdasarkan dari hasil tabel 6 dan 7 dapat dinyatakan bahwa corporate governance memiliki nilai probabilitas pada M1 lebih kecil dari 0,05 yakni 0,0079 dan nilai determinasi setelah uji moderasi lebih besar dari sebelumnya. Dari hasil tersebut mengindikasikan bahwa corporate governance dalam perusahaan manufaktur dapat memoderasi dan memperkuat hubungan kepemilikan manajerial terhadap agresivitas pajak dan hipotesis 2 diterima.

\section{PEMBAHASAN}

Pengaruh kepemilikan manajerial terhadap agresivitas pajak

Kepemilikan manajerial tidak memberi pengaruh signifikan terhadap agresivitas pajak di Indonesia. Penyebab kepemilikan manajerial tidak berpengaruh negatif terhadap agresivitas pajak dikarenakan nilai rata-rata tingkat kepemilikan manajerial dalam perusahaan manufaktur di Indonesia masih cukup rendah, yakni 16\%. Tingkat rasio kepemilikan manajerial yang masih rendah menandakan bahwa perusahaan bisa saja melakukan agresivitas pajak. Tingkat rasio yang rendah membuat kepemilikan manajerial tidak dapat memberikan keputusan secara signifikan yang berkaitan dengan kebijakan penekanan agresivitas pajak dalam perusahaan. Pada hasil penelitian ini sesuai dengan hasil penelitian Niandari et al. (2020); Prasetyo \& Pramuka (2018) yang menjelaskan tingkat kepemilikan manajerial tidak berpengaruh terhadap penghindaran pajak yang merupakan salah satu dari pelaksanaan agresivitas pajak, khususnya tingkat kepemilikan manajerial yang kurang dari $20 \%$.

Pengaruh kepemilikan manajerial terhadap agresivitas pajak, corporate governance sebagai variabel moderasi

Pada variabel corporate governance sebagai variabel moderasi pada penelitian ini dapat memberi pengaruh signifikan, sehingga dapat memoderasi dan memperkuat hubungan antara kepemilikan 
manajerial terhadap agresivitas pajak. Hal ini dapat terjadi karena corporate governance membantu kepemilikan manajerial dalam meminimalisir terjadinya agresivitas pajak melalui 5 penerapan asas yang ada di dalam corporate governance (Komite Nasional Kebijakan Corporate Governance, 2008). Corporate governance juga membantu perusahaan untuk meningkatkan kualitasnya dengan cara meninjau keefektifan audit internal, menilai sistem internal perusahaan, mereview laporan keuangan, serta menganalisis risiko yang ada maupun yang akan datang (Ikatan Komite Audit Indonesia, 2014). Oleh karena itu corporate governance dapat membantu kepemilikan manajerial dalam menekan agresivitas pajak pada suatu perusahaan. Pada hasil penelitian ini didukung oleh penelitian sebelumnya yang dilakukan oleh Davis et al. (2016); Zeng (2016) yang menjelaskan corporate governance mampu menekan penghindaran pajak yang dilakukan oleh perusahaan melalui pertanggungjawaban CSR kepada masyarakat.

\section{KESIMPULAN}

Berdasarkan hasil penelitian yang menggunakan 135 sampel perusahaan manufaktur yang terdapat dalam BEI dapat disimpulkan bahwa tingkat kepemilikan manajerial dalam perusahaan manufaktur cukup rendah. Tingkat kepemilikan manajerial yang rendah menandakan agresivitas pajak yang dilakukan oleh perusahaan semakin tinggi. Selanjutnya, corporate governance dapat memoderasi serta memperkuat hubungan kepemilikan manajerial terhadap agresivitas pajak dapat menekan agresivitas pajak dalam suatu perusahaan. Hal tersebut dapat menunjukkan bahwa corporate governance mampu membantu kepemilikan manajerial dalam menekan agresivitas pajak yang dilakukan oleh perusahaan.

Pada penelitian sebelumnya telah meneliti pengaruh kepemilikan manajerial terhadap praktik penghindaran pajak. Penelitian tersebut dilakukan oleh Cabello et al. (2019) yang menjelaskan kepemilikan manajerial dapat menekan tingkat penghindaran pajak dalam suatu negara, jika tingkat kepemilikan manajerial dalam sebuah perusahaan berada diatas $40 \%$. Berdasarkan hasil temuan tersebut, dapat diidentifikasikan bahwa tingkat rasio kepemilikan manajerial yang tinggi dapat mempengaruhi kebijakan yang dipilih perusahaan agar tidak melakukan penghematan pajak secara agresif. Selain itu, corporate governance mampu berperan penting dalam menekan agresivitas pajak yang dilakukan oleh perusahaan. Davis et al. (2016) menyatakan bahwa corporate governance dapat menekan penghindaran pajak dalam perusahaan melalui pertanggungjawaban CSR. Berdasarkan penemuan tersebut dapat disimpulkan bahwa corporate governance mampu membantu kepemilikan manajerial menekan agresivitas pajak dengan beberapa cara, salah satunya membantu kepemilikan manajerial menilai risiko, meningkatan transparansi laporan keuangan, dan pelaporan CSR kepada masyarakat.

Pada penelitian ini mempunyai beberapa keterbatasan diantaranya masih terbatasnya literasi yang berkaitan dengan penelitian ini serta tidak lengkapnya data-data yang ada di setiap laporan keuangan. Sehingga hasil yang diuji tidak secara keseluruhan dapat menginterpretasikan pengaruh kepemilikan manajerial terhadap agresivitas pajak di perusahaan manufaktur. Oleh karena itu, saran untuk penelitian kedepannya dapat menambahkan variabel-variabel yang berhubungan dalam mencegah agresivitas pajak dalam suatu perusahaan, seperti kepemilikan institusional dan kepemilikan publik; Dapat mengganti variabel kontrol menjadi return on investment (ROI) dan return on equity (ROE), karena dua variabel tersebut juga dapat memberikan pengaruh terhadap profit perusahaan; Dapat mengganti sampel objek penelitian dengan sektor lain, karena jenis perusahaan di Indonesia tidak hanya dari sektor manufaktur saja.

Berdasarkan hasil penelitian ini, pemerintah hendaknya memiliki kebijakan agar perusahaanperusahaan di Indonesia memiliki kepemilikan manajerial dan memaksimalkan adanya corporate governance di setiap perusahaannya. Corporate governance dan kepemilikan manajerial merupakan salah satu faktor terpenting dalam membantu pemerintah dalam menekan agresivitas pajak di perusahaan. Kepemilikan manajerial mampu menekan dengan cara membantu pihak manajer dalam menentukan keputusan tepat bagi perusahaan dan mengarahkan manajer agar tidak melakukan agresivitas pajak. Sedangkan, corporate governance dalam menekan agresivitas pajak dengan cara menjaga dan mengarahkan perusahaan agar tetap berpedoman dengan 5 asas corporate governance serta membantu kepemilikan manajerial agar bisa bekerja secara optimal. 
Jurnal Proaksi, Vol. 8 (2), Hal. 329 - 343

\section{REFERENSI}

Abdelfattah, T., \& Aboud, A. (2020). Tax Avoidance, Corporate Governance and Corporate Social Responsibility: The Case of the Egyptian Capital Market. "Journal of International Accounting, Auditing and Taxation, " 38, 100304. https://doi.org/10.1016/j.intaccaudtax.2020.100304

Allam, B. S. (2018). The Impact of Board Characteristics and Ownership Identity on Agency Costs and Firm Performance: UK evidence. Corporate Governance (Bingley), 18(6), 1147-1176. https://doi.org/10.1108/CG-09-2016-0184

Amidu, M., Coffie, W., \& Acquah, P. (2019). Transfer Pricing, Earnings Management and Tax Avoidance of Firms in Ghana. Journal of Financial Crime, 26(1), 25. https://doi.org/10.1108/JFC-10-2017-0091

Ayuntina, F. (2016). Analisa biaya relevan dalam pengambilan keputusan menghentikan atau melanjutkan produk genteng pada cv karang indah. 672013167, 0-15.

Bailey, F. . (1989). Intermediate Financial Management. In The British Accounting Review (Vol. 21, Issue 3). https://doi.org/10.1016/0890-8389(89)90100-5

Bimo, I. D., Prasetyo, C. Y., \& Susilandari, C. A. (2019). The Effect of Internal Control on Tax Avoidance: The case of Indonesia. Journal of Economics and Development, 21(2), 131-143. https://doi.org/10.1108/jed-10-2019-0042

Cabello, O. G., Gaio, L. E., \& Watrin, C. (2019). Tax Avoidance In Management-Owned Firms: Evidence from Brazil. International Journal of Managerial Finance, 15(4), 580-592. https://doi.org/10.1108/IJMF-04-2018-0117

Cuesta-González, M. D. la, \& Pardo, E. (2019). Corporate Tax Disclosure on a CSR Basis: A New Reporting Framework in The pPost-BEPS Era. Accounting, Auditing and Accountability Journal, 32(7), 2167-2192. https://doi.org/10.1108/AAAJ-12-2017-3282

Davis, A. K., Guenther, D. A., Krull, L. K., \& Williams, B. M. (2016). Do socially responsible firms pay more taxes? Accounting Review, 91(1), 47-68. https://doi.org/10.2308/accr-51224

Dyreng, S. D., Hanlon, M., \& Maydew, E. L. (2010). The Effects of Executives on Corporate Tax Avoidance. Accounting Review, 85(4), 1163-1189. https://doi.org/10.2308/accr.2010.85.4.1163

Eisenhardt, K. M. (1989). Agency Theory: An Assessment and Review. Academy Of Management, 59(1), 1-20. https://doi.org/10.5465/amr.1989.4279003

Fadhila, N. S., Pratomo, D., \& Yudowati, S. P. (2017). Pengaruh Kepemilikan Manajerial, Komisaris Independen dan Komite Audit terhadap Tax Avoidance. E-Jurnal Akuntansi, 21, 18. https://doi.org/10.24843/EJA.2017.v21.i03.p04

Fahmi, A. (2019). Keterkaitan antara Penerimaan Pajak Penghasilan dan Pbb Terhadap Kesenjangan Pendapatan. Jurnal Akuntansi: Kajian Ilmiah Akuntansi (JAK), 6(1), 39. https://doi.org/10.30656/jak.v6i1.945

Faysal, S., Salehi, M., \& Moradi, M. (2020). The Impact of Ownership Structure on The Cost of Equity in Emerging Markets. Management Research Review, 19. https://doi.org/10.1108/MRR-11-20190475

Feng, H., Habib, A., \& Tian, G. liang. (2019). Aggressive Tax Planning and Stock Price Synchronicity: Evidence from China. International Journal of Managerial Finance, 15(5), 829-857. https://doi.org/10.1108/IJMF-07-2018-0194

Governance, K. N. K. C. (2008). Good Public Governance Indonesia (K. N. K. Governance (ed.); 1st ed.). Komite Nasional Kebijakan Governance.

Hartadinata, O. S., \& Tjaraka, H. (2013). Analisis Pengaruh Kepemilikan Manajerial, Kebijakan Hutang dan Ukuran Perusahaan terhadap Tax Agressiveness. Jurnal Ekonomi Dan Bisnis, 23(3), 48-59. https://doi.org/10.20473/jeba.V23I32013.4517

Hidayat, W. W. (2018). Pengaruh Profitabilitas, Leverage dan Pertumbuhan Penjualan Terhadap Penghindaran Pajak. Jurnal Riset Manajemen Dan Bisnis (JRMB) Fakultas Ekonomi UNIAT, 3(1), 19-26. https://doi.org/10.36226/jrmb.v3i1.82 
Higgins, D., Omer, T. C., \& Phillips, J. D. (2015). The Influence of a Firm's Business Strategy on its Tax Aggressiveness. Contemporary Accounting Research, 32(2), 674-702. https://doi.org/10.1111/1911-3846.12087

Indonesia, I. K. A. (2014). Komite Audit. Ikai.Id. https://www.ikai.id/

Jayanto Purba, C. V, \& Kuncahyo, H. D. (2020). Pengaruh Profitabilitas, Likuiditas dan Leverage Terhadap Agresivitas Pajak pada Perusahaan Manufaktur yang Terdaftar Di Bei. Jurnal Bisnis Dharmawangsa, 2(1), 66-73. https://doi.org/10.46576/bisnis\%20net.v3i2.1005

Jensen, M. C., \& Meckling, W. H. (1976). Theory of The Firm: Managerial Behavior, Agency Costs and Ownership Structure. Human Relations, 72(10), 1671-1696. https://doi.org/10.1016/0304405X(76)90026-X

Kiesewetter, D., \& Manthey, J. (2017). Tax Avoidance, Value Creation and CSR - A European perspective. Corporate Governance (Bingley), 17(5), 803-821. https://doi.org/10.1108/CG-08$\underline{2016-0166}$

Kovermann, J., \& Velte, P. (2019). The Impact of Corporate Governance on Corporate Tax AvoidanceA literature Review. Journal of International Accounting, Auditing and Taxation, 36, 100270. https://doi.org/10.1016/j.intaccaudtax.2019.100270

Kutera, M. (2017). A model of aggressive tax optimization with the use of royalties. Journal of Economics and Management, 30(4), 85-98. https://doi.org/10.22367/jem.2017.30.05

La Rosa, F., Bernini, F., \& Verona, R. (2020). Ownership Structure and The Cost of Equity in The European Context: The mediating effect of earnings management. Meditari Accountancy Research, 28(3), 485-514. https://doi.org/10.1108/MEDAR-12-2018-0421

Liviani, S., Mahadwartha, P. A., \& Wijaya, L. I. (2016). Uji Model Keseimbangan Teori Keagenan: Pengaruh Kebijakan Utang dan Kebijakan Deviden terhadap Kepemilikan Manajerial. Development Research of Management, 11(1), 102-120. https://doi.org/10.19166/derema.v11i1.191

Lopo Martinez, A., \& Ferreira, B. A. (2019). Business Strategy and Tax Aggressiveness in Brazil. Journal of Strategy and Management, 12(4), 522-535. https://doi.org/10.1108/JSMA-03-20190040

Maharani, I. G. A. C., \& Suardana, K. A. (2014). Pengaruh Corporate Governance, Profitabilitas, dan Karakteristik Eksekutif pada Tax Avoidance Perusahaan Manufaktur. E-Jurnal Akuntansi, 9 (November), 525-539. https://ojs.unud.ac.id/index.php/Akuntansi/article/view/9290

Maraya, A. D., \& Yendrawati, R. (2016). Pengaruh Corporate Governance dan Corporate Social Responsibility Disclosure Terhadap Tax Avoidance: Studi empiris pada perusahaan tambang dan CPO. Jurnal Akuntansi \& Auditing Indonesia, 20(2), 147-159. https://doi.org/10.20885/jaai.vol20.iss2.art7

Mgammal, M. H. (2019). Corporate Tax Planning and Corporate Tax Disclosure. Meditari Accountancy Research, 2, 38. https://doi.org/10.1108/MEDAR-11-2018-0390

Mulyani, S., Wijayanti, A., \& Masitoh, E. (2018). Pengaruh Corporate Governance terhadap Tax Avoidance (Perusahaan Pertambangan yang terdaftar di BEI). Jurnal Riset Akuntansi Dan Bisnis Airlangga, 3(1), 322-340. https://doi.org/10.31093/jraba.v3i1.91

Munisi, G., Hermes, N., \& Randøy, T. (2014). Corporate Boards and Ownership Structure: Evidence from Sub-Saharan Africa. International Business Review, 23(4), 785-796. https://doi.org/10.1016/j.ibusrev.2013.12.001

Mutmainnah, M., Puspitaningtyas, Z., \& Puspita, Y. (2019). Pengaruh Kebijakan Dividen, Keputusan Investasi, Ukuran Perusahaan dan Kepemilikan Manajerial terhadap Nilai Perusahaan. Buletin Studi Ekonomi, 24(1), 18. https://doi.org/10.24843/bse.2019.v24.i01.p02

Neifar, S., \& Utz, S. (2019). The Effect of Earnings Management and Tax Aggressiveness on Shareholder Wealth and Stock Price Crash Risk of German Companies. Journal of Applied Accounting Research, 20(1), 94-119. https://doi.org/10.1108/JAAR-11-2016-0106 
Niandari, N., Yustrianthe, R. H., \& Grediani, E. (2020). Kepemilikan Manajerial dan Praktik Penghindaran Pajak. Owner (Riset Dan Jurnal Akuntansi), 4(2), 459. https://doi.org/10.33395/owner.v4i2.250

Ortas, E., \& Gallego-Álvarez, I. (2020). Bridging The Gap between Corporate Social Responsibility Performance and Tax Aggressiveness: The Moderating Role of National Culture. Accounting, Auditing and Accountability Journal, 33(4), 825-855. https://doi.org/10.1108/AAAJ-03-20172896

Prasetyo, I., \& Pramuka, B. A. (2018). Pengaruh Kepemilikan Manajerial, Kepemilikan Institusional, dan Proporsi Dewan Komisaris Independen terhadap Manajemen Laba. JEBDEER: Journal of Entrepreneurship, Business Development and Economic Educations Research, 20(2), 15. https://doi.org/10.32424/jeba.v20i2.1106

Prena, G. Das, Milawati, Kustina, K. T., \& Dewi, I. G. A. A. O. (2018). Pengaruh Ukuran Perusahaan, Jumlah Komisaris Independen dan Biaya CSR Terhadap Kecepatan Pelaporan Keuangan pada Perusahaan Otomotif dan Komponen yang Terdaftar di Bursa Efek Indonesia. Jurnal Ilmiah Akuntansi \& Bisnis, 3(1), 0-6. https://doi.org/10.38043/jiab.v3i1.2094

Runtu, T., \& Poputra, A. (2014). Analisis Dengan Menggunakan Informasi Akuntansi Diferensial Dalam Pengambilan Keputusan Membeli Atau Membuat Sendiri Bakso Pada Bakso Pasuruan. Jurnal Riset Ekonomi, Manajemen, Bisnis Dan Akuntansi, 2(2), 1440-1447.

Salehi, M., \& Salami, S. (2020). Corporate Tax Aggression and Debt in Iran. Journal of Islamic Accounting and Business Research, 11(1), 257-271. https://doi.org/10.1108/JIABR-10-2016$\underline{0127}$

Salehi, M., Tarighi, H., \& Shahri, T. A. (2019). The Effect of Auditor Characteristics on Tax Avoidance of Iranian Companies. Journal of Asian Business and Economic Studies. https://doi.org/10.1108/JABES-11-2018-0100

Salhi, B., Riguen, R., Kachouri, M., \& Jarboui, A. (2019). The Mediating Role of Corporate Social Responsibility on The Relationship between Governance and Tax Avoidance: UK Common Law versus French Civil Law. Social Responsibility Journal, April. https://doi.org/10.1108/SRJ-042019-0125

Saputra, A. (2020). Analisis Penerapan Perencanaan Pajak (Tax Planning) dalam Upaya Penghematan Beban Pajak Penghasilan Badan pada PT DCM Tahun 2017. Jurnal Pajak Vokasi, 1(2), 102-111. https://doi.org/10.31334/jupasi.v1i2.817.g457

Saputra, M. D. R., \& Asyik, N. F. (2017). Pengaruh Profitabilitas, Leverage, Dan Corporate Governance Terhadap Tax Avoidance. Jurnal Akuntansi Universitas Negri Padang, 6(8), 1-19. http://jurnalmahasiswa.stiesia.ac.id/index.php/jira/article/download/1485/1498

Sebayang, R. I. B. (2019, January 4). Dokumen: Google Lakukan Penghindaran Pajak Rp 327 Triliun. CNBC Indonesia, 1. https://www.cnbcindonesia.com/news/20190104214635-4-49236/dokumengoogle-lakukan-penghindaran-pajak-rp-327-triliun

Sintyawati, N. L. A., \& Dewi, M. R. (2018). Pengaruh Kepemilikan Manajerial, Kepemilikan Institusional dan Leverage Terhadap Biaya Keagenan pada Perusahaan Manufaktur. E-Jurnal Manajemen Universitas Udayana, 7(2), 933. https://doi.org/10.24843/EJMUNUD.2018.v7.i02.p16

$\mathrm{Su}, \mathrm{K}$. , Li, B., \& Ma, C. (2019). Corporate Dispersion and Tax Avoidance. Chinese Management Studies, 13(3), 706-732. https://doi.org/10.1108/CMS-04-2018-0497

Subekti, A. M., \& Amin, M. Al. (2019). Pengaruh Corporate Governance dan Insentif Eksekutif Terhadap Tax Avoidance (Studi Empiris Pada Perusahaan Pertambangan yang Terdaftar pada BEI Tahun 2009-2018). 2nd Prosiding Business and Economics Conference In Utilizing of Modern Technology 2019, 1(1), 16. http://journal.ummgl.ac.id/index.php/conference/article/view/3262

Sumantri, F. A., Anggraeni, R. D., \& Kusnawan, A. (2018). Corporate Governance terhadap Tax Avoidance pada Perusahaan Manufaktur yang Terdaftar di Bursa Efek Indonesia. Eco-Buss: Emerging Industries, 1(41), 124-139. https://doi.org/10.32877/eb.v1i2.47 
Sunarsih, U., \& Handayani, P. (2018). Pengaruh Corporate Governance Terhadap Penghindaran Pajak pada Perusahaan Manufaktur yang Terdaftar di Bursa Efek Indonesia. Jurnal Akuntansi, 12(2), 163-185. https://doi.org/10.25170/jara.v12i2.87

Suryandani, A. (2018). Pengaruh Pertumbuhan Perusahaan, Ukuran Perusahaan, dan Keputusan Investasi Terhadap Nilai Perusahaan pada Perusahaan Sektor Property dan Real Estate Di Bei. BMAJ:

$$
\text { Business Management Analysis Journal, 1(1), 49-59. }
$$
https://doi.org/10.24176/bmaj.v1i1.2682

Tambalean, F. A. K., Manossoh, H., \& Runtu, T. (2018). Pengaruh Kepemilikan Manajerial dan Kepemilikan Institusional Terhadap Nilai Perusahaan pada Perusahaan Sektor Industri Barang Konsumsi di Bei. Going Concern: Jurnal Riset Akuntansi, 14(1), 9. https://doi.org/10.32400/gc.13.04.21255.2018

Tiaras, I., \& Wijaya, H. (2015). Pengaruh Likuiditas, Leverage, Manajemen Laba, Komisaris Independen dan Ukuran Perusahaan terhadap Agresivitas Pajak. Jurnal Akuntansi, 19(3), 18. https://doi.org/10.24912/ja.v19i3.87

Utama, F., Kirana, D., \& Sitanggang, K. (2019). Pengaruh Penghindaran Pajak terhadap Biaya Hutang dan Kepemilikan Institusional sebagai Pemoderasi. Jurnal Bisnis Dan Akuntansi, 21(1), 47-60. https://doi.org/10.34208/jba.v21i1.425

Wahyuni, K., Aditya, E. M., \& Indarti, I. (2019). Pengaruh Leverage, Return On Assets dan Ukuran Perusahaan Terhadap Penghindaran Pajak pada Perusahaan Publik di Indonesia. Management \& Accounting Expose E-ISSN, 2(2), 116-123. https://doi.org/10.36441/accounting.v2i2.233

Wang, L. (2015). Tax Enforcement, Corporate Tax Aggressiveness, and Cash Holdings. China Finance Review International, 5(4), 339-370. https://doi.org/10.1108/CFRI-12-2014-0099

Wang, T. (2019). Product Market Competition and Efficiency of Corporate Tax Management. Asian Review of Accounting, 27(2), 247-272. https://doi.org/10.1108/ARA-07-2018-0136

Yee, C. S., Sapiei, N. S., \& Abdullah, M. (2018). Tax Avoidance , Corporate Governance and Firm Value in The Digital Era. Journal of Accounting and Investment, 19(2). https://doi.org/10.18196/jai.190299

Zeng, T. (2016). Corporate Social Responsibility, Tax Aggressiveness, and Firm Market Value. Accounting Perspectives, 15(1), 7-30. https://doi.org/10.1111/1911-3838.12090

Zhang, M., Lijun, M., Zhang, B., \& Yi, Z. (2016). Pyramidal Structure, Political Intervention and Firms' Tax Burden: Evidence from China's local SOEs. Journal of Corporate Finance, 36, 15-25. https://doi.org/10.1016/j.jcorpfin.2015.10.004 